\title{
Influence of Social Marketing on Rain Water Harvesting Practices for Water Recycling System
}

\author{
AV.Karthick, M.Ayisha Millath, R.Rajesh Karthik, M.Faisal
}

\begin{abstract}
Water is a limited natural resource for nourishing human life. Drinking water scarcity is one of the globally facing emerging issues. Harvesting is one among the major solution for this problem. There are three different ways of harvesting techniques like rainwater, ground water and flood water. Human health is intrinsically linked to the environment and water resources. Increasing water demand affecting more than majority of people throughout the world every year and are considered as a most critical risk to human sustainability. In the recent years social marketing is applied for general issues that are facing by public. This paper mainly focuses on the level of knowledge on water recycling. The study area is Sivagangai district. The sample size is 518 based on proportionate random sampling method. From this analysis they identified female are more aware on water harvesting.
\end{abstract}

Keywords: awareness, harvesting, health, limited, recycling, resources.

\section{INTRODUCTION}

Social Marketing is the extended version of marketing mix that deals with the various issues related to the society. It's a non-profit service oriented marketing field. (Deepak Chhabra et al. 2011) explained to understand the theory of social enterprise in the social marketing community and develop understand the awareness and apply of marketing within social enterprises. (Liping Yan et al. 2019) concerning the extent to which the inclusion of water issues between five chosen from English as well as Non-English newspaper sources distributed in Sydney uncovered that water issues were talked about. Media choice five papers in three languages English, Chinese and Korean, of among them 13 noteworthy subjects recognized, water contamination and improvement was the most much of the time examined theme followed by wet climate. The two papers considered the inclusion on the water dam condition.

(Yan Chen et al. 2019) explained the major issues are discussed like utilizing online networking information can help beat huge numbers of these disadvantages in spite of the

Revised Manuscript Received on July 22, 2019.

AV.Karthick, Research Scholar, Alagappa Institute of Management, Alagappa University, Karaikudi, India,Email: avkarthick@ gmail.com

Dr.M.AyishaMillath, Assistant Professor, Alagappa Institute of Management, Alagappa University, Karaikudi, India,Email: ayishamillath05@gmail.com.

R.Rajesh Karthik, Research Scholar, Alagappa Institute of Management, Alagappa University, Karaikudi, India, Email:rrajeshkarthik@gmail.com

M.Faisal, Research Scholar, Alagappa Institute of Management, Alagappa University, Karaikudi, India, Email:faisalfais.m@gmail.com fact that it has its very own impediments. User's with poor Internet openness or without the propensity for utilizing any or a specific online life. He insisted the Content based online networking like Twitter, has been utilized by decision makers in such settings to share data, tune in to sentiments, and encourage open talk. Picture sharing web based life destinations like Instagram and Flickr are up to this point underutilized.

(AV.Karthick et al., 2018) analysed the awareness level of waste water management among the household respondents in Sivagangai district municipalities. People are very little bit aware on waste water recycle and usage. (Alyssa M. Mayeda, 2018) Water hazard is one of the important Environmental issues, that is health effects associated with water resources includes contamination, illness and disease, weather-related incidents, lack of water and dehydration, recreational activities and accidents and respiratory-related health problems. Content analyses are common tool for systematically reviewing and analyzing the content of images, symbols, and bodies of text to produce data-driven inferences about their context. (Margaret Alston, 2014) paper traces water change strategy in Australia's Murray-Darling Basin territory. It diagrams the helplessness of people and networks and notes the requirement for activities to assemble flexibility and to empower change in these regions. (Daniel Goodwin, 2014) discussed there is a continuous test for water specialist organizations to usefully draw in with different societal concerns and to fabricate support for both the guideline of water reuse and singular tasks. (AV.Karthick, 2019) recent days digital technologies are applied in every sector.

(J.J. Haroua, 2014) evaluated the water is regularly proposed as a promising component to lessen water requests. It has three structures namely uniform, increasing block prices and decreasing block prices has every one of these cost structures is normally joined by a fixed water administration charge. Keen meters and In-Home Displays / versatile media applications are used to measure the possibly lessen water usage by changing the practices towards proactively mindful water use by purchasers. (M. Rae Moors, 2019) to explore the social media activism as a tool for social change and commentary, the role of affect in social media communication and location based social media understood together the support of two assertions.

(Cayce Myers, 2014) studied the issue of social media within workplace communications is a continually evolving issue that has a high likelihood of having changing laws and regulations because courts are uncertain how to apply traditional legal interpretations to ever changing social media. Despite the political and legal

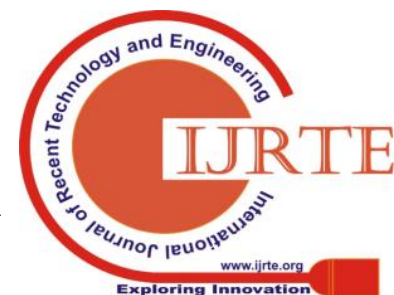


volatility of this issue, that pointed public relations practitioners should take away from these recent social media decisions. (Jamie N. Smith, 2018) examined the Web based life has turned into a significant piece of advertising for non-benefit associations. Internet based life can possibly draw in partners and constituents of non-benefit associations. The hierarchical web based life movement influences users from Facebook and Twitter reacted on philanthropic promotion gatherings.

(Cecilia Tortajada, 2011) investigates the job of the media in the Singapore and Malaysia in water supply, concentrating on the water arrangements between the time periods of 1997-2004. They identifies how the media gradually advanced from being principally a correspondent to turning into a functioning stage for correspondence between the invested individuals, acting both formally and informally, just as legitimately and unobtrusively, prompting molding general assessment in both of the two nations, especially with respect to their water relationship. Web related media in Singapore is less limited than print media however this is liable to questionable permitting guidelines. Radio and TV are claimed and controlled. The Internet, however still subject to some type of control, is the least confined sort of correspondence channel.

\section{REVIEW OF LITERATURE}

There are many research papers exploring the concept of social learning in environmental policy and water governance contexts. Some of these research papers are exploring the water based environmental issues on a more integrative approach and systemic understanding using systematic approach. Recent years Internet, face book, instagram etc plays a major role in creating awareness and somewhat they change the attitude. (Liping Yan et al. 2019) evidence shows the how matters identifying with water are ignored, among different media and to comprehend the conceivable impact on water issues among the various headings. His article deals about the water industries are facing the major challenges like dam condition, wet climate, dry spell and water framework issues all the more habitually. (Yan Chen et al. 2019) Online networking information ought to plainly enhance as opposed to supplant traditional methodologies. Instagram specifically can help pass on an image of individuals' everyday life in a scene, while it is going on, uncovering the inconsequential or worn-out things that might be less examined in dynamic methodologies in light of the strength of specific voices or analyst subjectivity.

(Daniel Goodwin, 2014) discussed there is a open dispositions and practices are known to be impacted by the media, which can modify open impression of hazard and trust in various wellsprings of data. Media confining may add to polarizing network frames of mind towards water the board. (Ifigeneia Koutiva, 2016) explained the two pieces of social research held in Athens quantitative poll gathering data in regards to the local water request frames of mind and practices and a progression of subjective meetings went for investigating inside and outside, the local water use dispositions and practices. (Jorgensen et al. 2009) led to writing survey of a few social models and reasoned that water utilization is affected legitimately by atmosphere and occasional components, socioeconomics, abiding attributes, family unit organization, past water use conduct and saw social control and by implication by the client's preservation expectation.

(Barry Liner, 2012) explained the water supply process consists of 'triple main concern' for maintainability in terms of monetary, social and ecological are concerned. Metropolitan water supply organizers must conform to state and national arrangements, oversee client request, address vulnerability, for example, environmental change, and spotlight on the TBL. The four major principles considering this are equity, social inclusion and interaction, security and adaptability. (Cayce Myers, 2014) this study explains the increasing use of social media by Americans are rising number of instances where workplace grievances are aired very publically on Facebook, Twitter, and blogs. While workplace complaints are once expressed in a conversation between friends, co-workers and family. The social media now allows these complaints viewed by millions of Internet users. Conversations via social media have direct implications for business public relations in that it affects the image, public perception and profitability.

(Lloyd James et al., 2015), explained RWH Technology has been used to supplement the conventional water supply systems, but its potential has not been fully exploited. (Sridhar Vedachalam, 2015) investigated the media talk on this issue, the print media on the central piped water and sewer rate expands for the time period of 1999 to 2012 and measured the impact. (Uta Wehn, 2017) to suggest that there are numerous creators investigates this idea of social learning in natural approach and water administration settings.

\section{OBJECTIVES OF THE STUDY}

- To compute the level of awareness among respondents in rainwater harvesting.

- To predict the influence of various sources of awareness on rainwater harvesting.

- To analyze the impact of rainwater harvesting on societal well-being.

- To offer possible suggestions to the decision maker for promoting water recycling activities.

\section{METHODOLOGY}

The study adopted descriptive and analytical research design, where the household respondents are from the Sivagangai district. It consists of three municipalities namely Karaikudi, Devakottai and Sivagangai. With the help of structured questionnaire using Raosoft calculator, where the actual sample size is 382 , but it was increased to 518 respondents for more accuracy. In this research we adopting, proportionate random sampling method for sample selection.

\section{ANALYSIS AND INTERPRETATION}

\section{A. Awareness level of Rain Water Harvesting}

General Linear model: Univariate analysis is performed to analyze whether there is a significant difference in level of awareness on considering various demographic profile of the respondents. 
$\mathrm{H}_{0}$ : There is no significant difference among the Sex, municipality, ownership, year when the building was built and Age with respect to the level of awareness on Rain water harvesting.

Table- I:Level of awareness of RainWater Harvesting

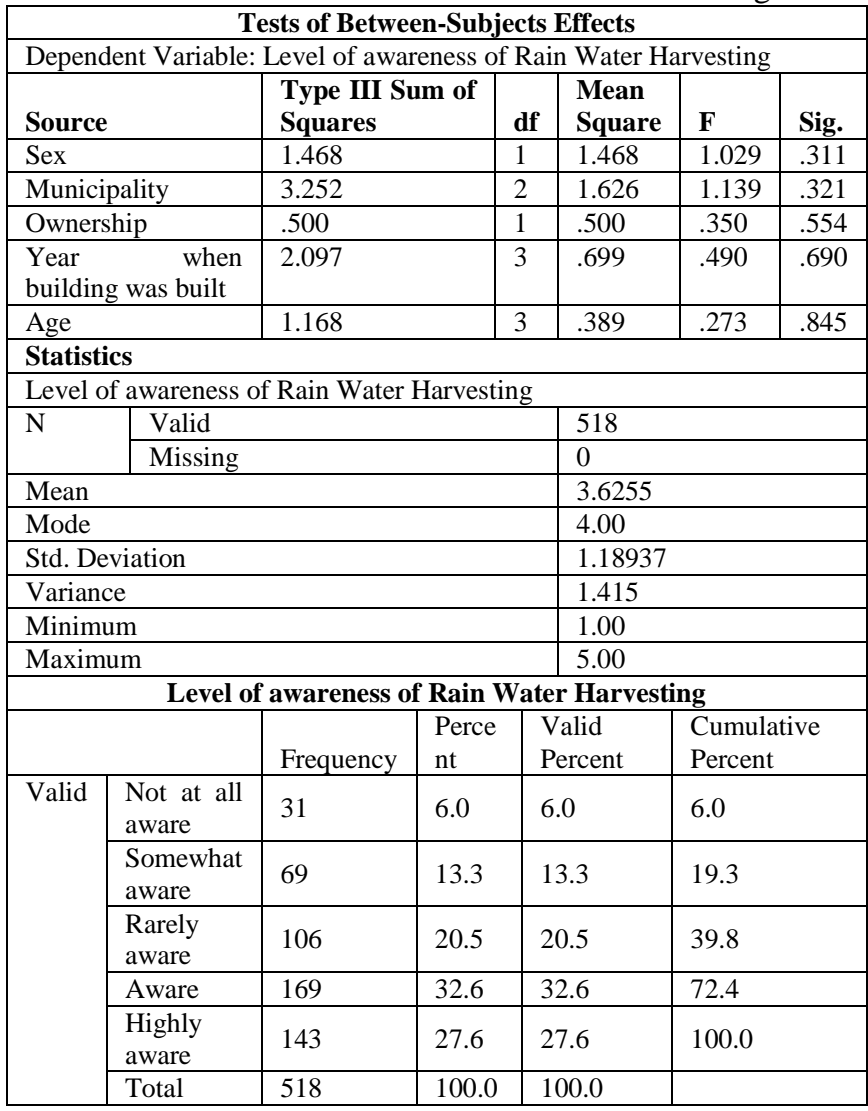

Source: (Primary data)

\section{Interpretation:}

The calculated significance value is greater than 0.05 , therefore the null hypothesis is accepted. Hence there is no significant difference in level of awareness on Rain water harvesting with respect to Sex, municipality, ownership, year when the building was built and age.

Mean value is estimated to be 3.6255 and mode value is identified to be 4 , which indicates most of the respondent have awareness on rain water harvesting.

\section{B. Social media and rain water harvesting awareness}

ANOVA and rank test using Mean score analysis were made to identify whether there is significant difference in various social media in creating awareness. Further to find out most effective social media in creating awareness on rain water harvesting.

$\mathrm{H}_{0}$ : There is no significant difference between the Sex, Municipality, Marital Status and Qualification with respect to various media in providing the source of information regarding Rain water harvesting.

Table- II: Various social media in creating awareness on Rain water harvesting

\section{Tests of Between-Subjects Effects}

\begin{tabular}{|c|c|c|c|c|c|c|}
\hline Source & & $\begin{array}{l}\text { Type } \\
\text { Sum } \\
\text { Squares }\end{array}$ & df & $\begin{array}{l}\text { Me } \\
\text { an } \\
\text { Squ } \\
\text { are }\end{array}$ & $\mathbf{F}$ & $\begin{array}{l}\mathrm{Si} \\
\text { g. }\end{array}$ \\
\hline Sex & Word of mouth & 8.532 & 1 & $\begin{array}{l}8.5 \\
32\end{array}$ & $\begin{array}{l}4.8 \\
29\end{array}$ & .02 \\
\hline & Newspaper & 1.795 & 1 & $\begin{array}{l}1.7 \\
95\end{array}$ & $\begin{array}{l}.96 \\
0\end{array}$ & $\begin{array}{l}.32 \\
8 \\
\end{array}$ \\
\hline & TV & .138 & 1 & $\begin{array}{l}.13 \\
8 \\
\end{array}$ & $\begin{array}{l}.08 \\
9 \\
\end{array}$ & $\begin{array}{l}.76 \\
6 \\
\end{array}$ \\
\hline & Serial Media & .208 & 1 & $\begin{array}{l}.20 \\
8\end{array}$ & $\begin{array}{l}.12 \\
2\end{array}$ & $\begin{array}{l}.72 \\
7\end{array}$ \\
\hline & $\begin{array}{l}\text { Government } \\
\text { Order }\end{array}$ & 3.205 & 1 & $\begin{array}{l}3.2 \\
05\end{array}$ & $\begin{array}{l}1.9 \\
09\end{array}$ & $\begin{array}{l}.16 \\
8\end{array}$ \\
\hline & $\begin{array}{l}\text { Social } \\
\text { Advertisement : } \\
\text { NGO, } \\
\text { Government } \\
\text { text books }\end{array}$ & 6.774 & 1 & $\begin{array}{l}6.7 \\
74\end{array}$ & $\begin{array}{l}4.2 \\
86\end{array}$ & $\begin{array}{l}.03 \\
9\end{array}$ \\
\hline $\begin{array}{l}\text { Munic } \\
\text { ipality }\end{array}$ & Word of mouth & 2.601 & 2 & $\begin{array}{l}1.3 \\
01\end{array}$ & $\begin{array}{l}.73 \\
6\end{array}$ & $\begin{array}{l}.47 \\
9\end{array}$ \\
\hline & Newspaper & 3.096 & 2 & $\begin{array}{l}1.5 \\
48\end{array}$ & $\begin{array}{l}.82 \\
8\end{array}$ & $\begin{array}{l}.43 \\
7\end{array}$ \\
\hline & TV & 1.304 & 2 & $\begin{array}{l}.65 \\
2 \\
\end{array}$ & $\begin{array}{l}.41 \\
9 \\
\end{array}$ & $\begin{array}{l}.65 \\
8 \\
\end{array}$ \\
\hline & Serial Media & 5.601 & 2 & $\begin{array}{l}2.8 \\
01\end{array}$ & $\begin{array}{l}1.6 \\
48\end{array}$ & $\begin{array}{l}.19 \\
4\end{array}$ \\
\hline & $\begin{array}{l}\text { Government } \\
\text { Order }\end{array}$ & .041 & 2 & $\begin{array}{l}.02 \\
0\end{array}$ & $\begin{array}{l}.01 \\
2\end{array}$ & $\begin{array}{l}.98 \\
8\end{array}$ \\
\hline & $\begin{array}{l}\text { Social } \\
\text { Advertisement : } \\
\text { NGO, } \\
\text { Government } \\
\text { text books }\end{array}$ & 1.997 & 2 & $\begin{array}{l}.99 \\
9\end{array}$ & $\begin{array}{l}.63 \\
2\end{array}$ & $\begin{array}{l}.53 \\
2\end{array}$ \\
\hline $\begin{array}{l}\text { Qualif } \\
\text { icatio }\end{array}$ & Word of mouth & 6.776 & 2 & $\begin{array}{l}3.3 \\
88\end{array}$ & $\begin{array}{l}1.9 \\
18\end{array}$ & $\begin{array}{l}.14 \\
8\end{array}$ \\
\hline $\mathrm{n}$ & Newspaper & 2.785 & 2 & $\begin{array}{l}1.3 \\
92\end{array}$ & $\begin{array}{l}.74 \\
5\end{array}$ & $\begin{array}{l}.47 \\
5\end{array}$ \\
\hline & TV & 2.705 & 2 & $\begin{array}{l}1.3 \\
53\end{array}$ & $\begin{array}{l}.87 \\
0\end{array}$ & $\begin{array}{l}.42 \\
0\end{array}$ \\
\hline & Serial Media & 1.311 & 2 & $\begin{array}{l}.65 \\
6\end{array}$ & $\begin{array}{l}.38 \\
6\end{array}$ & $\begin{array}{l}.68 \\
0\end{array}$ \\
\hline & $\begin{array}{l}\text { Government } \\
\text { Order }\end{array}$ & 1.430 & 2 & $\begin{array}{l}.71 \\
5\end{array}$ & $\begin{array}{l}.42 \\
6\end{array}$ & $\begin{array}{l}.65 \\
4\end{array}$ \\
\hline & $\begin{array}{l}\text { Social } \\
\text { Advertisement : } \\
\text { NGO, } \\
\text { Government } \\
\text { text books }\end{array}$ & 6.010 & 2 & $\begin{array}{l}3.0 \\
05\end{array}$ & $\begin{array}{l}1.9 \\
01\end{array}$ & $\begin{array}{l}.15 \\
0\end{array}$ \\
\hline
\end{tabular}

Mean Score Analysis Using Rank Test

\begin{tabular}{|c|c|c|c|c|c|c|}
\hline $\begin{array}{l}\text { Social } \\
\text { Media }\end{array}$ & Sex & $\mathbf{N}$ & \begin{tabular}{l|}
$\mathbf{M}$ \\
$\mathbf{e}$ \\
$\mathbf{a}$ \\
$\mathbf{n}$
\end{tabular} & $\begin{array}{l}\text { Ranks: Male } \\
\text { and Female }\end{array}$ & $\begin{array}{l}\text { Mean: } \\
\text { Male } \\
\text { and } \\
\text { Femal } \\
\text { e }\end{array}$ & $\begin{array}{l}\text { Rank: } \\
\text { Social } \\
\text { media }\end{array}$ \\
\hline \multirow[t]{2}{*}{$\begin{array}{l}\text { Word of } \\
\text { mouth }\end{array}$} & Male & $\begin{array}{l}2 \\
6 \\
9\end{array}$ & $\begin{array}{l}3 \\
4 \\
8 \\
7 \\
0\end{array}$ & 2 & \multirow[t]{2}{*}{3.5869} & \multirow[t]{2}{*}{3} \\
\hline & Female & $\begin{array}{l}2 \\
4 \\
9\end{array}$ & $\begin{array}{l}6 \\
8 \\
6 \\
7\end{array}$ & 1 & & \\
\hline \multirow[t]{2}{*}{$\begin{array}{l}\text { Newspap } \\
\text { er }\end{array}$} & Male & $\begin{array}{l}2 \\
6 \\
9\end{array}$ & $\begin{array}{l}3 \\
5 \\
5 \\
5 \\
7 \\
6\end{array}$ & 1 & \multirow[t]{2}{*}{3.4856} & \multirow[t]{2}{*}{5} \\
\hline & Female & $\begin{array}{l}2 \\
4 \\
9\end{array}$ & $\begin{array}{l}3 \\
3 \\
4 \\
1 \\
3 \\
7\end{array}$ & 2 & & \\
\hline
\end{tabular}


Influence of Social Marketing on Rain Water Harvesting Practices for Water Recycling System

\begin{tabular}{|c|c|c|c|c|c|c|}
\hline \multirow[t]{2}{*}{ TV } & Male & $\begin{array}{l}2 \\
6 \\
9\end{array}$ & $\begin{array}{l}3 \\
. \\
5 \\
2 \\
0 \\
4\end{array}$ & 2 & \multirow[t]{2}{*}{3.5293} & \multirow[t]{2}{*}{4} \\
\hline & Female & $\begin{array}{l}2 \\
4 \\
9\end{array}$ & $\begin{array}{l}3 \\
5 \\
5 \\
3 \\
8 \\
2 \\
\end{array}$ & 1 & & \\
\hline \multirow[t]{2}{*}{$\begin{array}{l}\text { Serial } \\
\text { Media }\end{array}$} & Male & $\begin{array}{l}2 \\
6 \\
9\end{array}$ & $\begin{array}{l}3 \\
. \\
5 \\
0 \\
9 \\
3\end{array}$ & 2 & \multirow[t]{2}{*}{3.5880} & \multirow[t]{2}{*}{2} \\
\hline & Female & $\begin{array}{l}2 \\
4 \\
9\end{array}$ & $\begin{array}{l}3 \\
6 \\
6 \\
6 \\
6 \\
7\end{array}$ & 1 & & \\
\hline \multirow[t]{2}{*}{$\begin{array}{l}\text { Govern } \\
\text { ment } \\
\text { Order }\end{array}$} & Male & $\begin{array}{l}2 \\
6 \\
9\end{array}$ & $\begin{array}{l}3 \\
. \\
2 \\
0 \\
4 \\
5\end{array}$ & 2 & \multirow[t]{2}{*}{3.3211} & \multirow[t]{2}{*}{6} \\
\hline & Female & $\begin{array}{l}2 \\
4 \\
9\end{array}$ & $\begin{array}{l}3 \\
. \\
4 \\
3 \\
7 \\
8\end{array}$ & 1 & & \\
\hline \multirow[t]{2}{*}{$\begin{array}{l}\text { Social } \\
\text { Advertis } \\
\text { ement : } \\
\text { NGO, } \\
\text { Govern } \\
\text { ment text } \\
\text { books }\end{array}$} & Male & $\begin{array}{l}2 \\
6 \\
9\end{array}$ & \begin{tabular}{l|}
3 \\
5 \\
7 \\
4 \\
7 \\
2 \\
\end{tabular} & 2 & \multirow[t]{2}{*}{3.7672} & \multirow[t]{2}{*}{1} \\
\hline & Female & $\begin{array}{l}2 \\
4 \\
9\end{array}$ & $\begin{array}{l}3 \\
. \\
7 \\
8 \\
7 \\
1 \\
\end{array}$ & 1 & & \\
\hline \multicolumn{7}{|c|}{$\begin{array}{l}\text { Test the significant diffe } \\
\text { municipalities }\end{array}$} \\
\hline $\begin{array}{l}\text { Social } \\
\text { Media }\end{array}$ & $\begin{array}{l}\text { Municip } \\
\text { ality }\end{array}$ & $\mathbf{N}$ & $\begin{array}{l}\mathbf{M} \\
\mathbf{e} \\
\mathbf{a} \\
\mathbf{n}\end{array}$ & $\begin{array}{l}\text { Rank: } \\
\text { Karaikudi, } \\
\text { Devakottai } \\
\text { and } \\
\text { Sivagangai }\end{array}$ & $\begin{array}{l}\text { Mean: } \\
\text { Karai } \\
\text { kudi, } \\
\text { Devak } \\
\text { ottai } \\
\text { and } \\
\text { Sivaga } \\
\text { ngai }\end{array}$ & $\begin{array}{l}\text { Rank: } \\
\text { Social } \\
\text { media }\end{array}$ \\
\hline \multirow[t]{3}{*}{$\begin{array}{l}\text { Word of } \\
\text { mouth }\end{array}$} & $\begin{array}{l}\text { Karaiku } \\
\text { di }\end{array}$ & $\begin{array}{l}1 \\
6 \\
1\end{array}$ & $\begin{array}{l}3 \\
6 \\
6 \\
2 \\
1 \\
1\end{array}$ & 2 & \multirow[t]{3}{*}{3.5887} & \multirow[t]{3}{*}{3} \\
\hline & $\begin{array}{l}\text { Devakot } \\
\text { tai }\end{array}$ & $\begin{array}{l}1 \\
9 \\
1\end{array}$ & $\begin{array}{l}3 \\
. \\
4 \\
7 \\
6 \\
4\end{array}$ & 3 & & \\
\hline & $\begin{array}{l}\text { Sivagan } \\
\text { gai }\end{array}$ & $\begin{array}{l}1 \\
6 \\
6\end{array}$ & $\begin{array}{l}3 \\
6 \\
6 \\
6 \\
8 \\
7\end{array}$ & 1 & & \\
\hline $\begin{array}{l}\text { Newspap } \\
\text { er }\end{array}$ & $\begin{array}{l}\text { Karaiku } \\
\text { di }\end{array}$ & $\begin{array}{l}1 \\
6 \\
1\end{array}$ & $\begin{array}{l}3 \\
5 \\
5\end{array}$ & 1 & 3.4892 & 5 \\
\hline
\end{tabular}

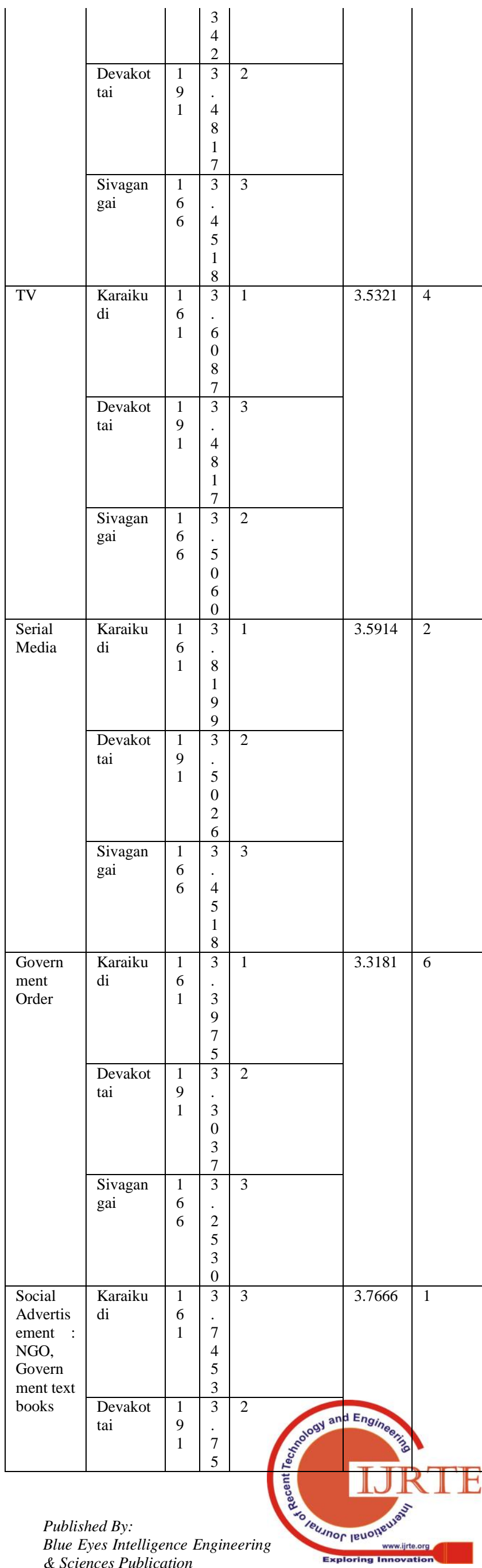




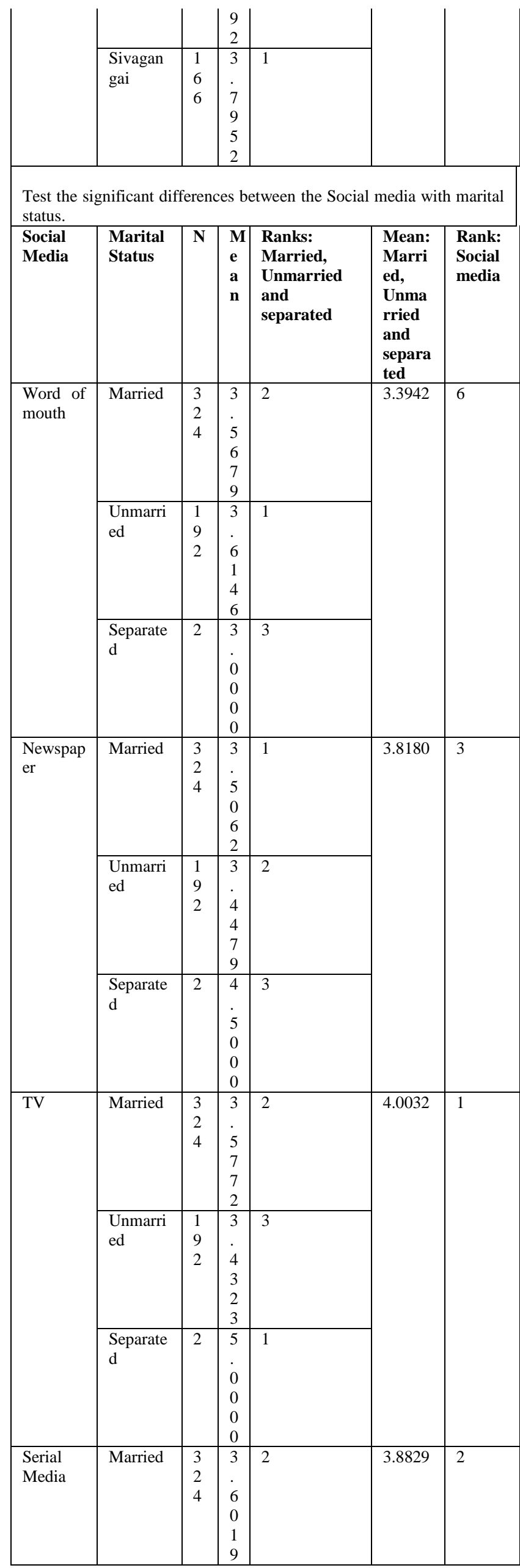

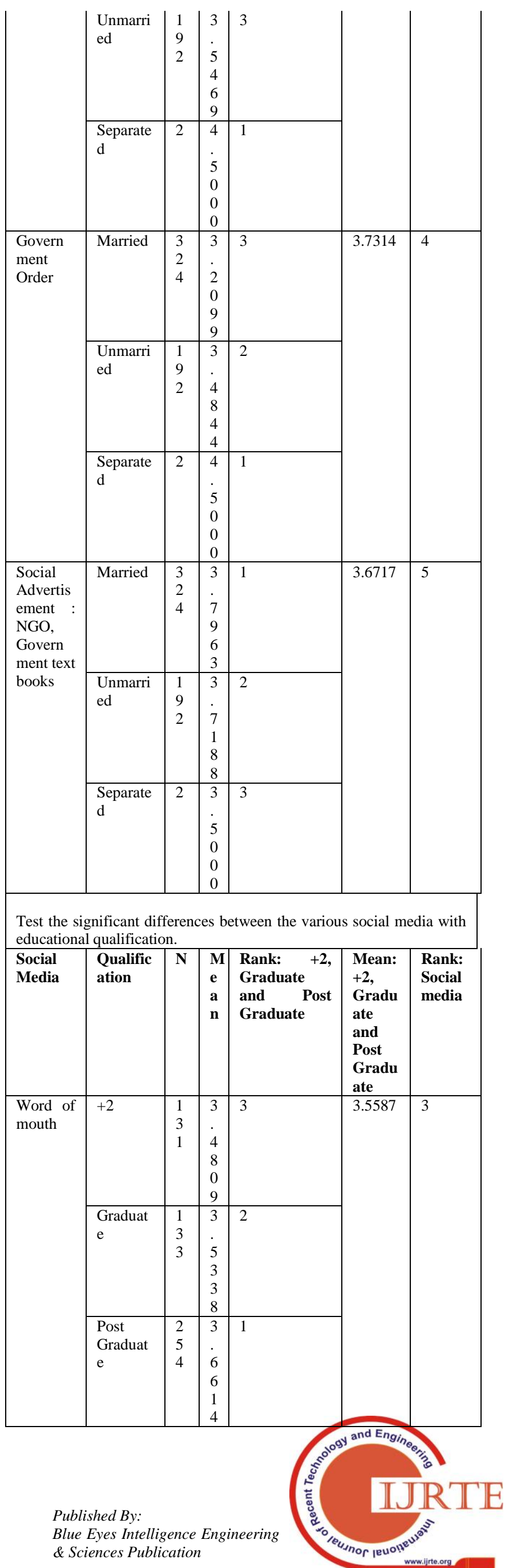




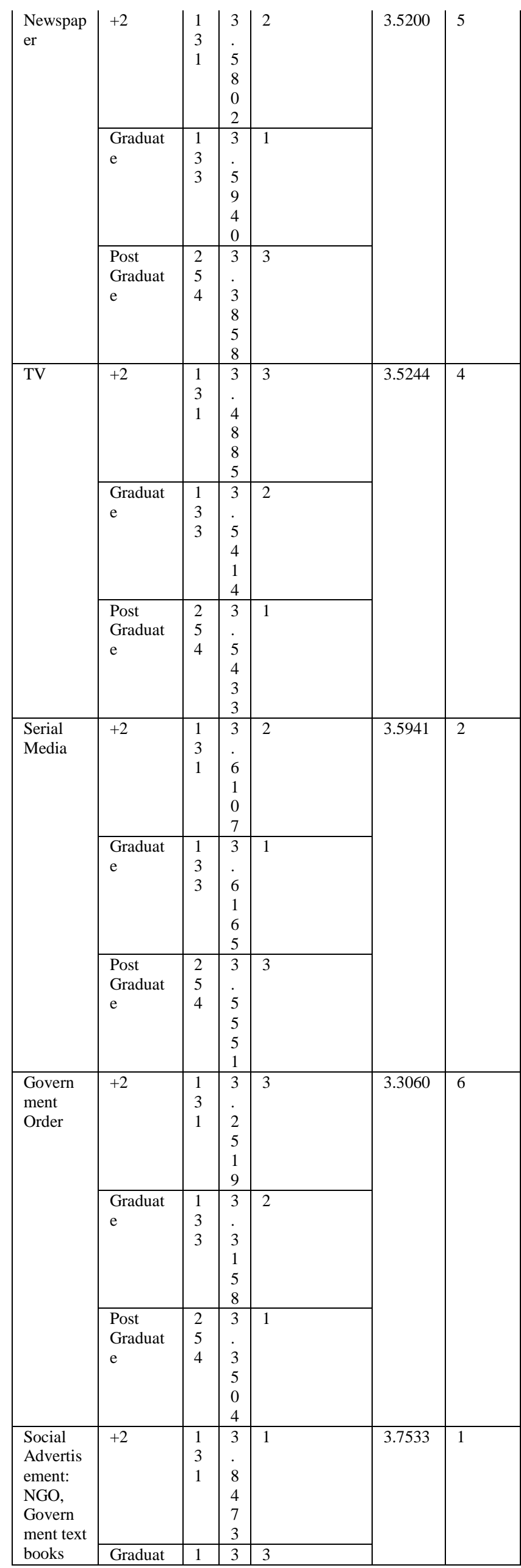

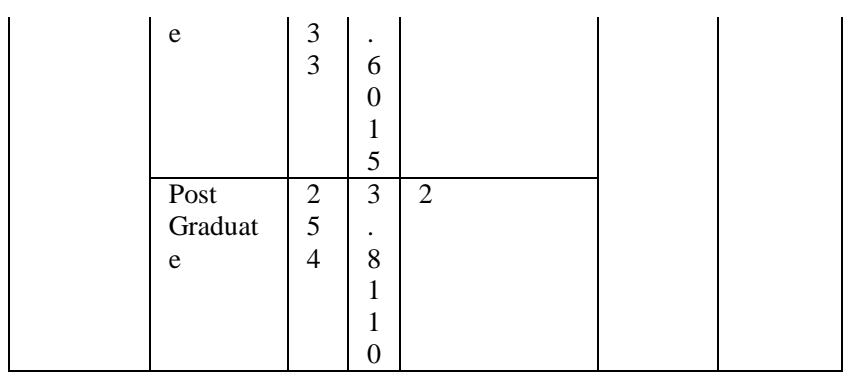

Source: (Primary data)

\section{Interpretation:}

Sex: The calculated significance value is greater than 0.05 , therefore the null hypothesis is accepted. Hence, there is no significant difference among various media in providing the source of information regarding Rain water harvesting with respect to Sex. Except of items "Word of Mouths and Social Advertisement: NGO, Government text books" the calculated significance value is lesser than 0.05 , therefore the null hypothesis is rejected. Hence, there is significant difference among various media in providing the source of information regarding Rain water harvesting with respect to Sex.

From rank test made using mean score, it can be interpreted that female had become more aware about rain water harvesting than male through social media such as Newspaper, TV, Serial Media, Government Order and Social Advertisement : NGO, Government text books. Further it was found that Social advertisement through NGO, Government text books and serial media were playing a vital role in bring awareness about Rain water harvesting.

Municipality: The calculated significance value is greater than 0.05 , therefore the null hypothesis is accepted. Hence, there is no significant difference among various media in providing the source of information regarding Rain water harvesting with respect to Municipality.

From rank test made using mean score, it can be interpreted that people of Karaikudi had become more aware about rain water harvesting than people of Devakottai and Sivagangai through social media such as Newspaper, TV, Serial Media and Government Order. Further it was found that Social advertisement through NGO, Government text books and serial media were playing a vital role in bring awareness about Rain water harvesting among people in various municipalities.

Qualification:The calculated significance value is greater than 0.05 , therefore the null hypothesis is accepted. Hence, there is no significant difference among various media in providing the source of information regarding Rain water harvesting with respect to Qualification.

From rank test made using mean score, it can be interpreted that Post Graduates become more aware about rain water harvesting than +2 and Under-graduates through Word of mouth, TV and Government Order. Further it was found that Social advertisement through NGO, Government text books and serial media were playing a vital role in bring awareness about Rain water harvesting among respondents with different qualification. 


\section{FINDINGS AND SUGGESTIONS}

Through the analysis it was found that most of the household respondents were aware about rain water harvesting. It can be well understood that female were more aware about rain water harvesting than male. Further among the people from different municipalities, people in Karaikudi were having more awareness on Rain water harvesting. Among the individual with different qualification, post-graduates possess better awareness on rain water harvesting. It can be well explicated that Social advertisements and serial media are playing an important role in creating awareness among people on Sivagangai district on rain water harvesting. It thereby recommended to the government and NGO's to provide more awareness programmes on Rain water harvesting. Further the awareness level about Rain water harvesting is not significant among male, so appropriate steps had to be taken to target male individuals while creating rain water harvesting programmes. It suggested to serial producer to integrate social welfare programme such as rain water harvesting as it is being an important influencing source in creating awareness. Moreover, it is perceived the awareness is more for Post Graduates compared to Under Graduates and +2 , hereby awareness on RWH should be brought at elementary level so that every individual in society getting educated would be aware about rain water harvesting. It is advised to NGO and other organization performing social awareness programme to focus on Devakottai and Sivagangai municipalities while creating rain water harvesting programme.

\section{CONCLUSION}

Government of India enforced RWH is mandatory for every household. People are constructed the RWH tank, but not they are not maintained them properly. Most of the people does not having clear differentiate between the rain water mixed with drainage water and they stored in RWH tank. Irrespective of the demographic profile, social advertisement and serials media were found to be an effective way to bring more awareness on rain water harvesting. It thereby recommended to the government and NGO's to provide more awareness programmes on Rain water harvesting. It is suggested to include rain water harvesting into the curriculum at elementary and primary level to create better awareness. It suggested to serial producer to integrate social welfare programme such as rain water harvesting as it is being an important influencing source in creating awareness.

\section{REFERENCES}

1. Alyssa M. Mayeda, Amanda D. Boyd, Travis B. Paveglio \& Courtney G. Flint (2018) Media Representations of Water Issues as Health Risks, Environmental 10.1080/17524032.2018.1513054

2. Andrea Ghermandi, Michael Sinclair (2019) Passive crowd sourcing of social media in environmental research: A systematic map, Global Environmental Change. DOI: 10.1016/j.gloenvcha.2019.02.003.

3. Ashleigh M. Day, Sydney O Shay-Wallace, Matthew W. Seeger \& Shawn P. McElmurry (2019) Informational Sources, Social Media Use, and Race in the Flint, Michigan, Water Crisis, Communication Studies, DOI: 10.1080/10510974.2019.1567566.

4. AV.Karthick, Dr.M.Ayisha Millath (2019) Management of Digital Libraries for Active Learning Environment: Trends and Challenges, Library Philosophy and Practice (e-journal).

5. AV.Karthick, Dr. M.Ayisha Millath (2018) Suggestive water treatment and conservation techniques among the Sivagnagai Civilan, International Journal of Advance and Innovative Research.

6. AV.Karthick, Dr. M.Ayisha Millath, S.Thowseaf (2018) Elucidating Water supply, demand and contamination in Tamilnadu, Shanlax International Journal of management.

7. AV.Karthick, Dr. M.Ayisha Millath, S.Thowseaf (2018) Water Recharge Realization and Cognizance habit among the Rural People, ICACSE, NIT Trichy.

8. Cayce Myers (2014) Social media as the new water cooler: Implications for PRpractitioners concerning the NLRB's stance on social media and workers' rights,Public Relations Review. DOI 10.1016/j.pubrev.2014.03.006.

9. Daniel Goodwin, Marie Raffin, Paul Jeffrey \& Heather M. Smith (2017) Evaluating media framing and public reactions in the context of a water reuse proposal, International Journal of Water Resources Development, DOI: $10.1080 / 07900627.2017 .1347085$

10. Deepak Chhabra, Kathy Andereck, Keiko Yamanoi, Dan Plunkett (2011) Gender Equity and Social Marketing: An Analysis of tourism advertisements, Journal of Travel \& Tourism Marketing. DOI: 10.1080/10548408.2011.545739.

11. Ifigeneia Koutiva, Patricia Gerakopoulou, Christos Makropoulos \& Christoforos Vernardakis (2016): Exploration of domestic water demand attitudes using qualitative and quantitative social research methods, Urban Water Journal, DOI 10.1080/1573062X.2015.1135968.

12. J.J. Harou, P. Garrone, A. E. Rizzoli, A. Maziotis, A. Castelletti, P. Fraternalid, J. Novak, R. Wissmann Alves, P.A. Ceschi (2014) Smart Metering, Water Pricing and Social Media to Stimulate Residential Water Efficiency: Opportunities for the SmartH2O Project, 16th Conference on Water Distribution System Analysis, WDSA DOI: $10.1016 /$ j.proeng.2014.11.222.

13. Jamie N Smith (2018) The Social Network? Nonprofit Constituent Engagement Through Social Media, Journal of Nonprofit \& Public Sector Marketing, DOI: 10.1080/10495142.2018.1452821.

14. Kevin Gatt (2016) Social network analysis as a tool for improved water governance in Malta, International Journal Society Systems Science. DOI: 10.1504/IJSSS.2016.077013.

15. Liping Yan, Phil McManus \& Elizabeth Duncan (2019) Ethnicity and media: a study of English and non-English language print media coverage of water issues in Sydney, Local Environment, DOI: 10.1080/13549839.2019.1588868.

16. Lloyd James S Baiyegunhi (2015) Determinants of rainwater harvesting technology (RWHT) adoption for home gardening in Msinga, KwaZulu-Natal, South Africa, Water SA. DOI: 10.4314/wsa.v4lil.6.

17. M. Rae Moors (2019) What is Flint? Place, storytelling, and social media narrativereclamation during the Flint water crisis, Information, Communication \& Society, DOI: 10.1080/1369118X.2019.1577477.

18. Margaret Alston and Kerri Whittenbury (2014) Social impacts of reduced water availability in Australia's Murray Darling Basin: adaptation or maladaptation, International Journal of Water. DOI: 10.1504/IJW.2014.057777.

19. Margaret O. Wilder, Ismael Aguilar-Barajas, Nicolas Pineda-Pablos, Robert G. Varady, Sharon B. Megdal, Jamie McEvoy, Robert Merideth, Adriana A. ZunigaTeran \& Christopher A. Scott (2016) Desalination and water security in the US-Mexico border region: assessing the social, environmental and political impacts, Water International, DOI: 10.1080/02508060.2016.1166416.

20. Middle East Water Commission (1995) Observations Regarding Water Sharing and Management: An Intensive Analysis of the Jordan River Basin with Reference to Long-distance Transfers, International Journal of Water Resources Development, DOI: 10.1080/07900629550042083.

21. Raechel Johns (2014) Community change: Water management through the use of social media, the case of Australia's Murray-Darling Basin, Public Relations Review. DOI: 10.1016/j.pubrev.2014.09.002.

22. Robert Case \& Lea Caragata (2009) The Emergence of a New Social Movement:Social Networks and Collective Action on Water Issues in Guelph, Ontario, Community Development, DOI: 10.1080/15575330903091738.

23. S. E. Wolfe \& David B. Brooks (2016) Mortality awareness and water decisions: a social psychological analysis of supply-management demand-management and soft-path paradigms, Water International, DOI: $10.1080 / 02508060.2016 .1248093$.

24. Sridhar Vedachalam, Bruce V. Lewenstein, Kelly A. DeStefano, Shira D. Polan \& Susan J. Riha (2015) Media discourse on ageing water infrastructure, Urban Water Journal, DOI: 10.1080/1573062X.2015.1036087.

25. Tortajada C \& Pobre K (2011) The Singapore - Malaysia water relationship: an analysis of the media perspectives, Hydrological Science Journal. DOI: 10.1080/02626667.2011.579074. 
26. Uta Wehn, Kevin Collins, Kim Anema, Laura Basco-Carrera \& Alix Lerebours (2017) Stakeholder engagement in water governance as social learning: lessons from practice, Water International, DOI: 10.1080/02508060.2018.1403083.

27. W.D. Evans, S.K. Pattanayak, S. Young, J. Buszin, S. Rai, Jasmine Wallace Bihm (2014) Social marketing of water and sanitation products: A systematic review of peer-reviewed literature, Social Science \& Medicine. DOI: 10.1016/j.socscimed.2014.03.011.

28. Wang Xifeng, Zhou Zuhao, Yang Guiyu \& Jia Yangwen (2012) Development of Social-natural Dualistic Water Cycle Model and Dynamic Assessment of Water Resources in Hun River Basin in China, HKIE Transactions. DOI: 10.1080/1023697X.2012.10668256.

29. Yan Chen, John R. Parkins \& Kate Sherren (2019) Leveraging Social Media to Understand Younger People's Perceptions and Use of Hydroelectric Energy Landscapes, Society \& Natural Resources, DOI: $10.1080 / 08941920.2019 .1587128$ 